\title{
Perilaku Religius Anak Usia 5-6 Tahun pada PAUD Model Karakter
}

\author{
Ifina Trimuliana ${ }^{1 凶}$, Nurbiana Dhieni ${ }^{2}$, Hapidin ${ }^{3}$ \\ Pendidikan Anak Usia Dini, Universitas Negeri Jakarta
}

\begin{abstract}
Abstrak
Penelitian ini bertujuan untuk mengetahui bentuk-bentuk perilaku religius, proses terbentuknya perilaku religius dan peran lingkungan dalam membentuk perilaku religius anak usia 5-6 tahun di Taman Kanak-kanak Ar-rahman Motik Jakarta. Penelitian ini menggunakan pendekatan kualitatif dengan metode studi kasus. Hasil penelitian menemukan bahwa bentuk perilaku religius anak usia 5-6 tahun di Taman Kanak-kanak Ar-rahman Motik Jakarta adalah anak terbiasa mengucap dan membalas salam, anak hafal doa dan surat-surat pendek, hafalan bacaan serta gerakan sholat, berinfaq, berbagi sesama teman, mendokan kedua orang tua dan sesama muslim.
\end{abstract}

Keywords: perilaku religious; pendidikan karakter; anak usia dini

\begin{abstract}
This study aims to study the religious forms of religion, the process of religious formation and the role of the environment in shaping religious children aged 5-6 years in the Ar-Rahman Motik Kindergarten Jakarta. This study used a qualitative case study method. The results of the study found that a way of religious learning of children aged 5-6 years in kindergarten Ar-Rahman Jakarta are children who need to say and reply to the greetings, children memorize the prayers and the short letters, memorizing readings and prayer movements, praying, giving thanks share fellow friends, guide both parents and fellow Muslims.
\end{abstract}

Keywords: religious behavior, character education; early childhood

Copyright (c) 2019 Ifina Trimuliana, Nurbiana Dhieni, Hapidin

$\triangle$ Corresponding author:

Address : Jalan pemuda Rawamangun, Pulogadung, Jakarta

ISSN 2356-1327 (Media Cetak)

Email : ifina_trimuliana@yahoo.com

ISSN 2549-8959 (Media Online) 


\section{PENDAHULUAN}

Membentuk karakter yang positif diperlukan pendidikan sedini mungkin. Sebagaimana Rosmiati mengemukakan bahwa, pendidikan anak usia dini memiliki peran yang besar dalam membangun dan membentuk karakter jangka panjang. Artinya pendidikan anak usia dini menjadi faktor penentu karakter anak di masa yang akan datang. Baik atau tidaknya karakter seseorang tergantung dari pembentukan karakternya pada waktu usia dini.

Untuk membentuk karakter dibutuhkan pembinaan yang tepat. Sabi'ati (2016) menjelaskan bahwa, pendidikan merupakan media paling sistematis dan efektif untuk memperkuat pembinaan karakter peserta didik. Oleh karena itu, pendidikan karakter hendaknya menjadi komitmen bersama semua pihak yang berada di lembaga pendidikan. Pendapat ini menjelaskan bahwa pendidikan karakter merupakan upaya-upaya yang dirancang dan dilaksanakan secara sistematis untuk membantu anak memahami nilai-nilai perilaku karakter. Pendidikan tersebut membutuhkan kerja sama antara semua pihak. Berarti membentuk karakter bukan hanya tugas seorang guru, tapi tugas bersama semua pihak yang terlibat dalam pendidikan tersebut.

Pentingnya pembentukan karakter diungkapkan oleh Delat dalam Shoshani (2018) yaitu pembentukan karakter anakanak merupakan salah satu tujuan utama sosialisasi pendidikan. Kebanyakan orang tua ingin menanamkan kualitas moral dasar pada anak. Orang tua berharap untuk membesarkan anak-anak yang memiliki pujian yang baik dan diinginkannya sifat yang baik serta memiliki kepribadian yang dijiwai oleh etika. Dari kutipan ini, dapat dipahami bahwa pendidikan adalah wadah untuk membentuk karakter. Oleh karena itu tujuan utama pendidikan adalah untuk membentuk kepribadian anak yang berkarakter. Taman Kanak-kanak Arrahman Motik merupakan salah satu lembaga pendidikan anak usia dini yang memiliki kurikulum karakter. Kurikulum tersebut berbasiskan agama Islam dengan visi utamanya yaitu membentuk insan yang akhlakul karimah. Oleh karena itu pembelajaran di sekolah ini lebih mengutamakan pembentukan karakter agar anak memiliki perilaku yang menjiwai nilai-nilai karakter. Sesuai dengan hasil wawancara yang dilakukan dengan kepala sekolah, lembaga ini mengutamakan pembentukan karakter atas dasar petimbangan bahwa karakter tidak akan terbentuk begitu saja melainkan dengan proses yang panjang melalui pembiasaan. Berdasarkan hasil observasi pada pelaksanaan kurikulum karakter ini terlihat perilaku religius anak. Adapun perilaku yang terlihat yaitu, anak terbiasa mengucap dan membalas salam, anak hafal doa dan surat-surat pendek, hafalan bacaan serta gerakan sholat, hafalan asma ulhusna dan hafalan hadist pendek. Dengan memiliki perilaku religius seperti yang digambarkan di atas, menjadikan sekolah ini mampu meraih berbagai prestasi. Prestasi yang diraih anak antara lain, juara lomba bacaan surat pendek, bacaan doa-doa harian dan manasik haji. Selain itu, terlihat perilaku religius anak dalam bersosialisasi dengan temannya, seperti mengucapkan Istighfar apabila temannya marah. Memiliki perilaku religius seperti yang dijelaskan di atas tentu menjadi keunggulan tersendiri bagi sekolah ini yang membedakan dengan sekolah yang lainnya karena religius merupakan suatu hal yang sangat penting dalam kehidupan manusia, seperti halnya yang disampaikan oleh Nurhalim (2017) bahwa pendidikan moral religius penting dilakukan sejak dini secara konsisten dan berkelanjutan. Banyak penyimpangan yang terjadi disebabkan 
lemahnya sistem pendidikan moral dan religius. Oleh karena itu penting ditanamkan nilai-nilai moral dan religius agar penyimpangan tersebut dapat diatasi. Berarti pendapat ini mempertegas bahwa membentuk moral dan religius sangat penting diberikan sejak usia dini agar anak terhindar dari perilaku yang menyimpang.

Religius memberikan batasan dalam kehidupan sehari-hari. Seperti yang diungkapkan oleh Brainerd dan Menon (2019) religius menentukan banyak ritual kehidupan sehari-hari. Religius juga menentukan mana yang boleh dilakukan dan mana yang tidak, serta membatasi makanan mana yang boleh dimakan dan mana yang tidak. Pendapat ini menjelaskan bahwa sikap religius bagi seseorang menjadi panutan dalam kehidupan sehariharinya. Sikap dan perilakunya tidak terlepas dari aturan yang ada dalam agama yang di anutnya. Oleh karena itu, orang yang religius bertindak berdasarkan aturan yang ada dalam agama yang dianutnya.

Sejalan dengan pendapat Hemming (2015) menyatakan bahwa religius merupakan sesuatu yang menekankan pada kepercayaan. Religius juga berkaitan dengan perilaku ritual yang berhubungan dengan kepercayaan. Kepercayaan tersebut yang mencakup afiliasi dan kepemilikan, perilaku dan praktik, kepercayaan dan nilainilai, dan pengalaman agama dan spiritual. Jadi pendapat ini menjelaskan bahwa religius berkaitan dengan kegiatan spiritual yang dilakukan oleh seseorang dalam kehidupan sehari-harinya. Spiritual ini muncul berdasarkan kepercayaan yang dianutnya. Jadi religius merupakan sesuatu sikap mental seseorang yang berhubungan dengan kepercayaan terhadap agama tertentu, serta perilaku patuh terhadap ajaran agama tersebut dengan menjalankan ibadah-ibadah tertentu dalam kehidupan sehari-hari.
Masa usia dini merupakan masa pembentukan perilaku anak. Anak akan membentuk perilakunya dengan meniru orang dewasa yang berada di sekitarnya. Morisson (2016) mengemukakan bahwa pembelajaran terjadi utamanya lewat modeling, observasi, keteladanan pengalaman dan pengaturan diri dengan melewati empat tahapan, yaitu: 1) Memperhatikan orang lain. 2) Memilih perilaku-perilaku tertentu untuk direproduksi. 3) Mengingat perilakuperilaku yang diamati. 4) Mereproduksi ulang perilaku yang diamati. Berdasarkan pendapat ini terlihat bahwa modeling merupakan sesuatu hal yang sangat penting dalam pembentukan perilaku anak karena masa usia ini adalah masa anak suka meniru. Karakter yang dimiliki oleh anak adalah hasil tiruannya dari karakter orang yang ada di lingkungan sekitarnya.

Nashikhah (2016) menjelaskan bahwa perilaku-perilaku anak usia dini dapat kembangkan melalui penjadwalan secara terus menerus. Penjadwalan yang dilakukan diharapkan melekat pada anak secara kuat dan menjadi bagian dari perilaku positif yang dimilikinya. Berdasarkan pendapat di atas, ditegaskan bahwa kedisiplinan dan pembiasaan seharihari berperan penting dalam membentuk karakter anak. Penjadwalan dan pembiasaan menjadikan karakter positif melekat pada diri anak. Jadi proses terbentuknya perilaku religius pada anak usia dini yaitu diawali dengan memberikan pemahaman tentang nilai-nilai religius pada anak yang diikuti dengan contoh serta pembiasaan perilaku orang dewasa agar anak dapat melihat perilaku tersebut dengan konkrit sehingga menimbulkan rasa butuh untuk menerapkan perilaku tersebut.

Pembentukan prilaku religisu dapat dilakukan dengan pembelajaran sentra, sebagaimana yang diteliti oleh Iswantiningtyas \& Wulansari bahwa Sentra 
masak membantu anak untuk memiliki pengalaman yang unik dalam mengenal tentang berbagai bahan makanan. Pada sentra ini anak dapat belajar tentang berbagai konsep sanis, matematika dan sosial, sehingga dapat menunjang perkembangan kognitif, bahasa, sosialemosional, motorik, agama dan seni. Adapapun nilai pendidikan karakter yang ditanamkan religius dan rasa ingin tahu.(Iswantiningtyas \& Wulansari, 2019)

Karakter anak di sekolah tidak terlepas dari pengaruh pola asuh masingmasing keluarga. Prasanti dan Fitriani (2018) menyatakan bahwa pembentukan karakter diawali dari pengaruh keluarga, dilanjutkan oleh sekolah dan komunitas. Berdasarkan pendapat tersebut bahwa keluarga merupakan faktor pertama dan utama dalam pembentukan karakter anak. Sebelum anak mendapatkan pendidikan dari lingkungan sekolah terlebih dahulu anak mendapatkan pendidikan dari orang tuanya. Cara orang tua memperlakukan anak berpengaruh terhadap pembentukan karakter dan karakter tersebut terlihat dari perilaku anak.

Pendapat lain juga mengatakan bahwa bahwa orang tua merupakan faktor utama pembentukan karakter anak. Hsin dan Chen (2014) menyatakan bahwa orang tua adalah faktor utama dalam pembentukan karakter anak. Aturan yang diterapkan di sekolah harus sejalan dengan aturan yang diterapkan oleh orang tua selama anak di rumah. Aturan ini dapat dilakukan secara alami dengan menerapkan dalam kehidupan sehari-hari melalui pembiasaan. Pendapat ini menegaskan bahwa orang tua merupakan faktor utama pembentukan karakter anak, salah satunya yaitu perilaku religius. Berdasarkan uraian di atas dapat disintesiskan bahwa orang tua dan keluarga adalah peran utama dalam membentuk perilaku religius anak sehingga orang tua harus mengajarkan perilaku yang baik kepada anak serta menyesuaikan dan membiasakan aturan yang ada di sekolah dengan aturan yang ada di rumah agar anak tetap berada di lingkungan yang memiliki nilai perilaku religius.

Selain pendapat di atas, pembentukan karakter juga bergantung pada ada tidaknya kesadaran berbagai pihak terhadap pendidikan. Mulyasa mengungkapkan bahwa pendidikan karakter tepat jika diimplementasikan sejak dini, yaitu sejak anak belajar di lembaga pendidikan anak usia dini seperti Taman Kanak-kanak (TK) atau Raudhatul Athfal (RA). Pendidik merupakan sebagai salah satu pembentuk karakter anak usia dini. Sedangkan sekolah merupakan wadah dalam menciptakan suasana pembelajaran untuk membentuk karakter anak. Oleh karena itu pendidik memberikan contoh yang baik bagi anak didiknya.

Juanda dalam penelitiannya terkait pembentukan karakter dengan menggunakan fabel menemukan bahwa pembentukan karakter anak usia dini dapat dilakukan dengan pengasuhan anak usia dini (sejak bayi) dan pendidikan dini anakanak dengan cara yang sejalan dengan orientasi perspektif anak, yaitu:1.Melihat anak itu sebagai pribadi; 2.Keikutsertaan yang empati dengan anak; 3.Sikap interpretatif menghormati anak ungkapanungkapan dan arti kehidupan dunia; 4.Membimbing anak dengan cara yang sensitif dengan menyesuaikan dan memperluas inisiatif mereka dan cara-cara pemahaman ke arah tujuan atau objek pendidikan, seperti mendukung dan mendorong minat dan keterlibatan emosional dan eksplorasi dalam tugas dan kegiatan yang penting untuk perkembangan mereka; dan 5.Perawatan dini dan pendidikan adalah proses dialogis antara anak dan pengasuh/guru, keduanya berkontribusi pada tujuan pembelajaran terkadang guru dominan.(Juanda, 2019) 
Selama berada di sekolah guru merupakan sosok penentu dalam membentuk karakter anak. Gunawan (2017) menjelaskan peran guru sebagai berikut:

The formation of a child's character needs to be realized by every parent and teacher, therefore parents and teachers should have a focus on shaping the character of the child. Child characters can be formed through each senses they have, especially the eyes and hearing. Children often imitate what they see and hear from their surroundings, such as their parents and relatives and friends. What they see and hear they imitate through their daily behavior.

Kutipan ini menjelaskan bahwa pembentukan karakter anak perlu diwujudkan oleh setiap orang tua dan guru. Oleh karena itu, orang tua dan guru harus memiliki fokus pada pembentukan karakter anak. Karakter anak dapat dibentuk melalui setiap indera yang mereka miliki, terutama mata dan pendengaran. Anak-anak suka meniru perilaku orang yang ada di lingkungannya. Pendapat ini menegaskan bahwa karakter anak terbentuk berdasarkan apa yang dilihat dan didengar oleh anak dari lingkungan tempat tinggalnya. Selama anak berada di sekolah guru adalah teladan dalam pembentukan perilaku religius. Jadi dapat disimpulkan bahwa peran sekolah dalam membentuk perilaku religius anak yaitu sekolah merupakan wadah pembentuk perilaku yang mengutamakan peran guru sebagai modeling dan controling bagi anak agar memiliki perilaku religius dalam kehidupan sehari-hari.

Sedangkan konten yang diajarkan meliputi kegiatan religius sehari-hari yang biasa dilakukan oleh anak

Establishing religious values and morals for children at Kindergarten revolves around the activities of daily life. Specifically establishing religious values to children of kindergarten is laying the foundations of the faith, personality or character commendable and habits of worship according to their ability (Mubasyaroh, 2016)

\section{METODOLOGI}

Metode penelitian yang digunakan dalam penelitian ini adalah studi kasus. Studi kasus merupakan suatu tipe kajian penelitian kualitatif yang memfokuskan pada suatu objek tunggal, individu, suatu kelompok, suatu institusi atau lembaga, suatu organisasi. Pada penelitian ini, peneliti ingin mendeskripsikan atau memotret suatu gejala nyata atau situasi sosial yaitu perilkau religius anak usia 5-6 tahun di Taman Kanak-kanak Ar-rahman Motik Jakarta, secara luas dan mendalam tanpa melakukan intervensi.

Teknik pengumpulan data menggunakan observasi, wawancara dan dokumentasi. Teknik analisa data dilakukan dengan mencocokan pola atau pattern matching Yin (2014). Dalam penelitian ini menggunakan teknik penjodohan Campbell. Analisis ini menurut Yin ialah dengan membandingkan pola yang didasarkan pada pola empirik dengan pola yang telah diprediksi di awal sebelum mengumpulkan data. Jika kedua pola ini ada persamaan, hasilnya dapat menguatkan validitas internal studi kasus yang bersangkutan.

\section{HASIL DAN PEMBAHASAN}

Hasil penelitian didapatkan bahwa perilaku religius anak usia 5-6 tahun di Taman Kanak-kanak Ar-rahman Motik Jakarta adalah bahwa anak menjadikan landasan agama Islam untuk berperilaku dalam kehidupan sehari-hari yaitu membiasakan diri mengucap dan membalas salam, berdoa sebelum dan sesudah kegiatan, menghafal surat-surat pendek AlQur'an, belajar praktek wudhu' dan sholat, memasukkan uang infaq ke dalam kotak amal, mendoakan kedua orang tua dan sesama muslim, dan berbagi makanan. 


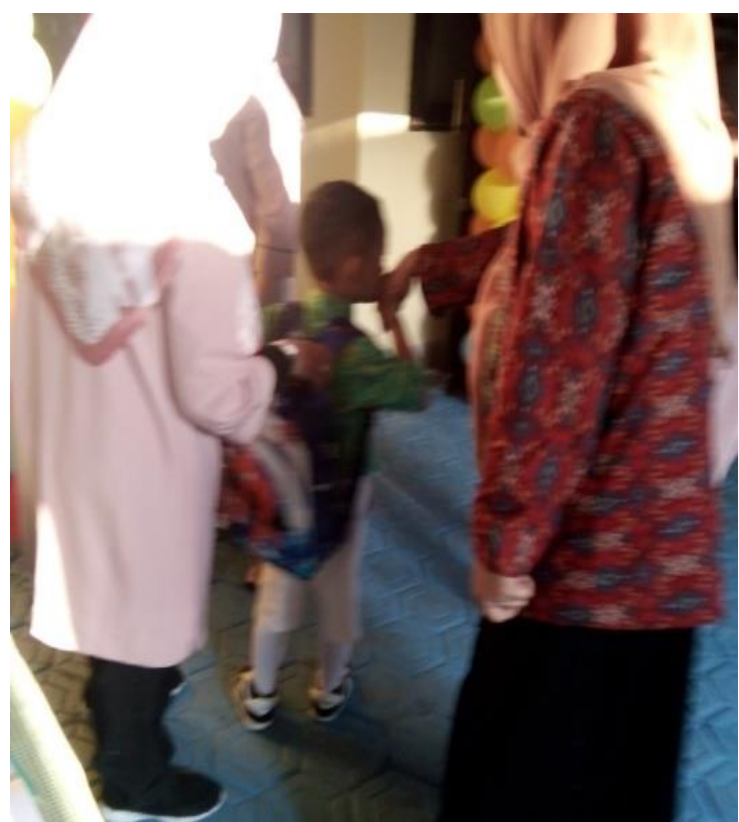

Gambar anak bersalaman dengan guru

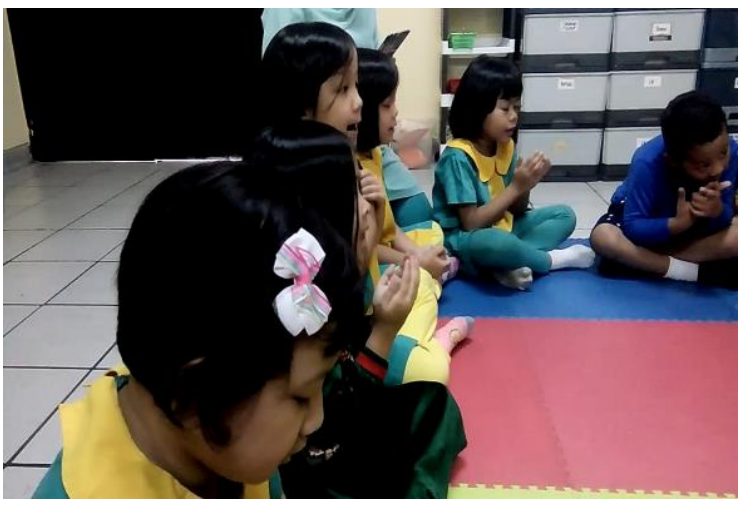

Gambar anak berdoa sebelum mmemulai kegiatan

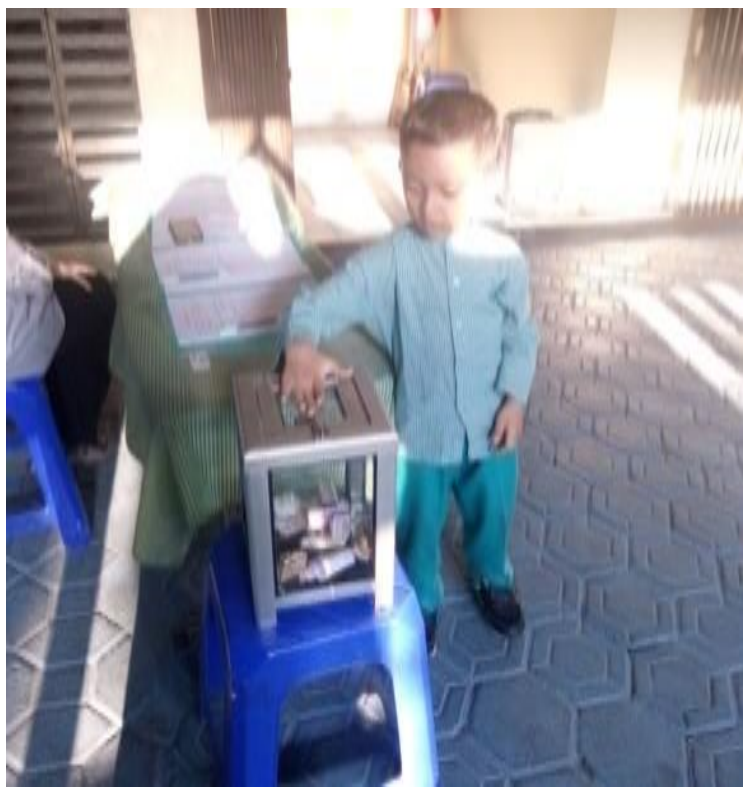

Gambar anak memasukkan uang infaq ke dalam kotak amal

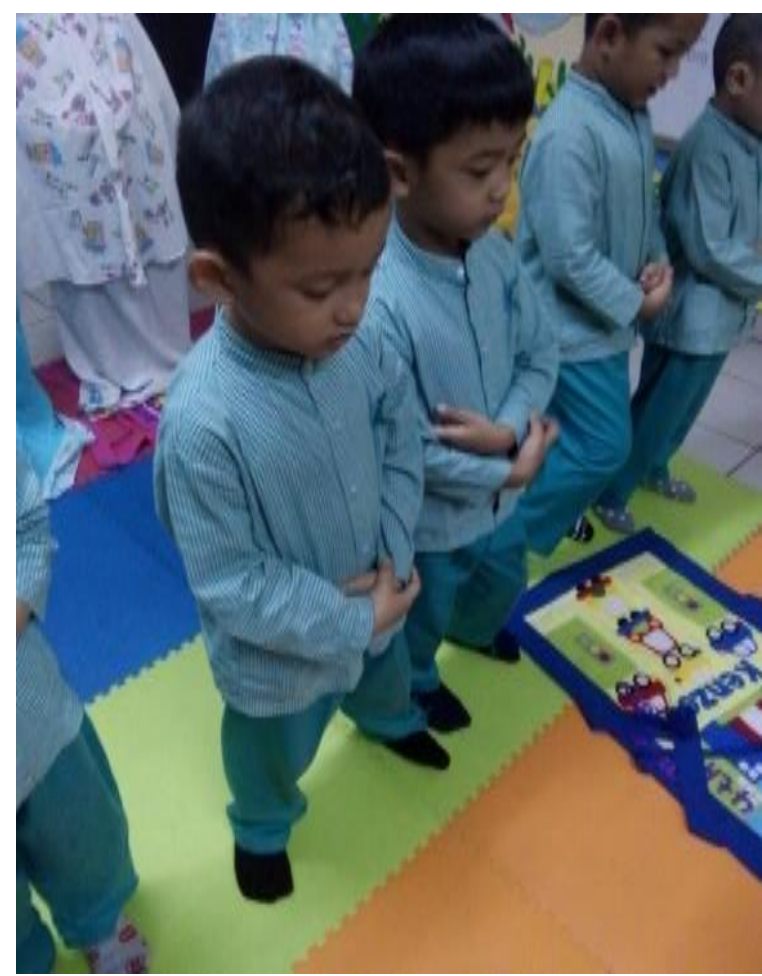

Gambar anak sholat berjamaah

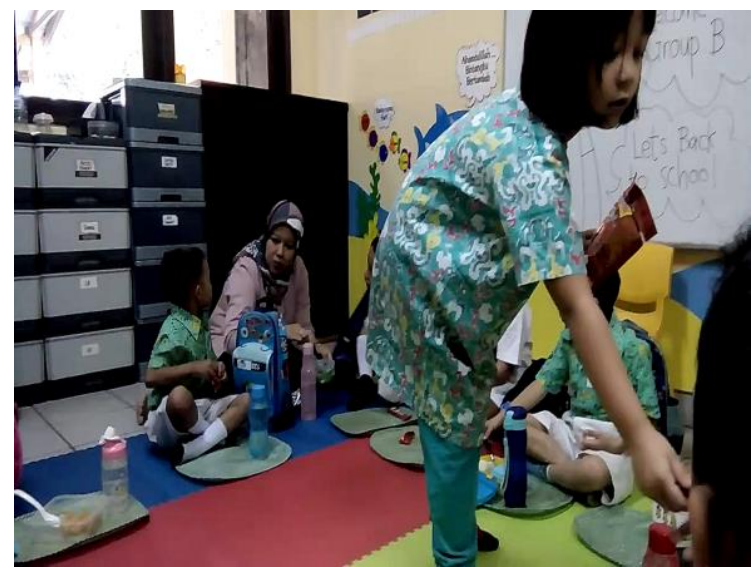

Gambar anak berbagi makanan dengan temannya

Fadlillah (2016) mengungkapkan bahwa religius merupakan sikap dan perilaku yang patuh terhadap pelaksanaan agama yang dianutnya. Sikap religius juga menunjukkan rasa toleransi tehadap pemeluk agama lain. Kutipan di atas menjelaskan bahwa religius tidak bisa dipisahkan aktivitas beribadah seseorang. Kepatuhan terhadap agama menjadikan seseorang merasa butuh terhadap aktivitas beribadah. Agama juga menjadi pedoman hidup bagi individu yang religius sehingga memiliki sikap toleransi terhadap agama 
lain. Bentuk-bentuk perilaku religius seperti yang ditemukan di Taman Kanak-kanak Arrahman Jakarta sejalan dengan hasil penelitian yang dilakukan oleh Kuswardani (2015) karakter religius anak di daerah pesisir terlihat dari beberapa kegiatan, seperti sholat berjamaah di mesjid, memberi dan membalas salam, berdoa sebelum dan sesudah kegiatan dan hafalan bacaan suratsurat pendek. Selanjutnya penelitian oleh Mubasyaroh (2016) hasil penelitian ini mengungkapkan bahwa dalam budaya tertentu nilai-nilai religius dengan meletakkan dasar iman. Selain itu, juga membentuk kepribadian atau karakter yang tampak dalam praktek terpuji dan kebaktian. Nilai-nilai ini diimplementasikan sesuai dengan kemampuan anak seperti pembiasaan perilaku yang baik dalam kehidupan sehari-hari. Maksud pembiasaan perilaku dalam kutipan ini adalah bahwa anak dibiasakan untuk membaca dua kalimat syahadat, berwuduk, sholat dan berdoa, puasa di bulan ramadhan serta membayar zakat. Perilaku-perilaku seperti ini merupakan dasar iman seseorang dalam kehidupan beragama.

Penelitian lainnya oleh Hasanah (2018) menyebutkan bahwa implementasi dari Pendidikan Agama Islam melalui penanaman budaya religius. Budaya ini dilakukan melalui berbagai jenis kegiatan keagamaan yang dilaksanakan di luar jam pelajaran. Artinya perilaku religius terlihat pada kegiatan keagamaan tambahan yang dilakukan di luar jam pelajaran, seperti siswa melaksanakan sholat dhuha, sholat zuhur berjamaah dan membaca membaca Al Qur'an.

Mutakin dan Rusmana (2014) menemukan bahwa dimensi perilaku religius siswa di tingkat sekolah dasar yaitu sholat lima waktu dan pembacaan Al Qur'an. Sholat ini sebelum diberikan treatmen baru dapat dilaksanakan oleh siswa dalam kehidupan sebesar 36,82\%.
Setelah diberikan treatment metode pembiasaan, pelaksanaan shalat lima waktu dan pembacaan ayat-ayat Al Qur'an mengalami peningkatan yang cukup signifikan, dari $36,82 \%$ menjadi 57,13 .

\section{KESIMPULAN}

Taman Kanak-kanak Ar-rahman Motik Jakarta merupakan salah lembaga pendidikan anak usia dini yang mengutamakan pembentukan karakter dalam pembelajaran. Oleh karena itu, hasil penelitian menemukan anak usia 5-6 tahun memiliki perilaku religius yang terlihat dalam kebiasaan sehari-hari anak seperti membiasakan diri untuk mengucap dan membalas salam, berdoa sebelum dan sesudah kegiatan, menghafal surat-surat pendek Al-Qur'an, belajar praktek wudhu' dan sholat, bersedekah untuk orang yang kurang mampu, mendoakan kedua orang tua dan sesama muslim.

\section{UCAPAN TERIMA KASIH}

Penulis mengucapkan terima kasih kepada Yayasan Paud Arr-Rahman Motik Jakarta yang telah memberikan ijinan untuk melakukan penelitian dan membantu mengumpulkan data. Penulis juga mengucapkan terima kasih kepada dosen pembimbing yang telah membantu penulis dalam menyempurnakan tulisan ini. Ucapan terima kasih juga disampaikan kepada tim editor jurnal obsesi yang telah memberikan saran, kritik dan masukan untuk perbaikan artikel ini.

\section{DAFTAR PUSTAKA}

Brainerd, E., \& Menon, N. (2019). Religion and Health in Early Childhood: Evidence from South Asia Religion and Health in Early Childhood: Evidence. 41(3), 439-463.

Fadlillah, M. (2016). Pendidikan Karakter Anak Usia Dini. Jakarta: 
Prenadamedia Group.

Gunawan, R. (2017). The Role of Character Education for Early Children in Early Childhood Education Programs in Happy Kids Bogor Indonesia. 66(Yicemap), 23-26.

Hasanah, F. (2018). Implementation Of Islamic Religious Education Through Cultivating Religious Culture in SMP 21 Malang City. 6(2), 273-292.

Hemming, P. J. (n.d.). Childhood, Youth, and Religious Identity: Mapping the Terrain. $1-18$. https://doi.org/10.1007/978-981-458591-0

Iswantiningtyas, V., \& Wulansari, W. (2019). Penanaman Pendidikan Karakter pada Model Pembelajaran BCCT (Beyond Centers and Circle Time). Jurnal Obsesi: Jurnal Pendidikan Anak Usia Dini, 3(1), 110. https://doi.org/10.31004/obsesi.v3i1.1 06

Juanda, J. (2019). Pendidikan Karakter Anak Usia Dini melalui Sastra Klasik Fabel Versi Daring. Jurnal Obsesi: Jurnal Pendidikan Anak Usia Dini, 3(1), 39. https://doi.org/10.31004/obsesi.v3i1.1 26

Kuswardani, H. (2015). Karakter Religius Anak Di Daerah Pesisir.

Morisson. (2016). Pendidkan Anak Usia Dini Saat Ini. Yogyakarta: Pustaka Belajar.

Mubasyaroh, M. (2016). Model of Religious Study and Moral Values in TK Putra Harapan Nalumsari Jepara. Ta'dib, 21(2), 191. https://doi.org/10.19109/td.v21i2.1029

Mulyasa. (2014). Manajemen Paud. Bandung: PT Remaja Rosdakarya.

Mutakin, T. Z., \& Rusmana, I. M. (2014). Kota Tangsel memiliki motto. 1(3), 361-373.
Nadlifah. (2015). Revitalisasi Pendidikan Karakter Di Paud Terpadu Aisyiah Nur'aini Yogyakarta. 1(2).

Nashikhah, M. (2016). Peranan Soft Skill Dalam Menumbuhkan Karakter Anak TPA Ma' rifatun Nashikhah. 01(1), 33-39.

Nurhalim, K., \& Artikel, I. (2017). Pola Penanaman Nilai Nilai Moral Religius di TK It Arofahh 3 Bade Klego Boyolali. 3(1), 53-59.

Rosmiati, A. (2014). Teknik Stimulasi dalam Pendidikan Karakter Anak Usia Dini melalui Lirik Lagu Dolanan. 15(1), 71-82.

Sabi'ati, A. (2016). Membangun Karakter AUD Dalam Pembangunan Nilai Agama Dan Moral di RA Masyithoh Pabelan Kabupaten Semarang. 2(1), $1-14$.

Shoshani, A. (2018). Young children's character strengths and emotional well-being: Development of the Character Strengths Inventory for Early Childhood. The Journal of Positive Psychology, 9760(January), $1-17$.

https://doi.org/10.1080/17439760.2018 .1424925

Yin, R. K. (2014). Case Study Research: Design and Methods (5th ed.). USA: SAGE. 